\title{
Sunarno
}

Lecturer, Faculty of law, Universitas Muhammadiyah Yogyakarta; Ph.D Candidate International Islamic University Malaysia.

Jalan Lingkar Selatan Tamantiro, Kasihan Bantul, Yogyakarta 55183. Email: narno_muhdayahoo.com

\section{INCORPORATING GOOD LAND GOVERNANCE IN THE DISASTER REGION OF YOGYAKARTA}

\begin{abstract}
Land is one of the most major capitals in our life. Without it, sustainability of human existence is very impossible. Unfortunately, land problems in Indonesia have unique challenges compared to other countries. Many of kinds of challenges are in the form of the natural disasters. This paper is going to measure how well the principles of good governance has been incorporated in the Yogyakarta Special Region Land administration System generally by studying on the Merapi Disaster Mitigation, particularly in how land planning for the Merapi Disaster's victims is performed. The research methodology employs a combined research method, it means that fundamental principles in process and its output of both the doctrinal and non doctrinal approaches is synergized to based on the research's activity unites. Configuration of the land administration systems in achieving people prosperity has been affected by evolution of political, cultural, and legal awareness of local communities and central government policy. To conclude, incorporating a disaster response based land policy principles requires an integrated law and policy making system among parties through the implementation of good governance principle in the record of public participation voices and sustainable development interests. Notable reports illustrate that the good land governance incorporation encouraged and inspired land planning system to be more efficient and effective. Particularly in the natural disaster mitigation and reconstruction, incorporating good land governance principles furthermore encourages land policy makers to achieve the responsive land management in line with social demands and sustainable development programs.
\end{abstract}

Key Words: good governance principles, land administration system, land policy, disaster response 


\section{$2_{\text {JURNAL MEDIA HUKUM }}$}

\section{INTRODUCTION}

Land is one of the most major capitals in our life. Without it, sustainability of human existence is very impossible. As shown in daily reality, all human necessities do need the land. For instance, housing, various roads, markets, and other infrastructures need sufficient parcels of land. Briefly, No private and public sectors can be exist without land. The dense human needs on land encourage wildly land problems (See Land \& Equity, 2006, 1-6).

Unfortunately, land problems in Indonesia have unique challenges compared to other countries. Many of kinds of challenges are in the form of the natural disasters. So many victims of disaster such as mountain eruption and earthquake at anywhere gave lessons Indonesian Government to generate a good idea, particularly in facing land problems. The responsive mitigation, the sustainable land planning, a good management of natural resources are believed as three instances of the break through to handle numerous risks.

Three reasons are as the most well known characteristics of the Yogyakarta Special Region Land Administration which could be a fundamental background on this research, as follows: Firstly, the existing strong kingdom still strongly manages land matter, particularly for sultanate ground. Secondly the land matter of Yogyakarta Special Region frequently faced natural disasters. Lastly, many of successful land management are shown with less land complaints supposed to others. For last reason, wonderful achievements have been proven with succeeding on land planning in the Bantul District's earthquake mitigation programs and the Merapi Mountain's eruption mitigation

The Further reason, from the earliest ages of the Indonesian entity when people still struggling and defending the freedom, Yogyakarta has achieved the exposure of modernizing the land administration system toward good land governance system. The chains of chronological sequels that were signed with many events such as the old type of land democratization in 1918 with issuing the Rijblad 1918, land planning management post natural disaster - Bantul's earthquake and Sleman'sMerapi Eruption -, and Yogyakarta' win with acknowledgement as the Yogyakarta Special Region based on the Act No 13/2012 confirmed that incorporating good principles on numerous aspects of land administration system has continuously gone on the proper track in the circumstance of - called as - a feudal power. It is a obvious problematic, incorporating a modern value of land administration under an old type oflocal political power.

For interconnected reasons above, this paper is going to measure how well the principles of good governance has been incorporated in the Yogyakarta Special Region Land administration System generally by studying on the Merapi Disaster Mitigation, particularly in how land planning for the Merapi Disaster's victims is performed

\section{RESEARCH METHOD}

In the answer the research problem, the research methodology employs a combined research method, it means that fundamental principles in process and its output of both the doctrinal and 


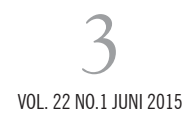

non doctrinal approaches is synergized to based on the research's activity unites. It carries consequences that the research considers both kinds of the empirical and library studies and conducting both kinds of qualitative that supported by quantitative analysis as long as any necessity. Taking conclusion is generated by both inductive and deductive legal thought. Basically because this study were not only classified non-doctrinal research, so there is a need analyzing documents, related legislation, relevant cases, and secondary legal materials relating to the research topic.

\section{ANALYSIS}

\section{A. Land Administration and Good Governance}

Land administration cannot be simply interpreted as technical aspects without the principle of land values, as the legal framework explains:

"These land administration systems may include processes to manage public land, record and register private interests in land, assess land value, determine property tax obligation, define land use, and support the development application and approval process. However by only those mechanic steps of land administration without a fundamental element, land is still surrounded by more and more of land problems. The fundamental element pointed out is good governance that must be incorporated in land administration system"

Other conditions showed that land administration system cannot be separated with the principles of good governance, as well as all policies will be greatly affected by the political system of a country.

In equivalent meaning, bad governance is coming because of absence of principles of good governance and will give birth to bad land administration system, as revealed:

"A bad configuration among them will produce a poor land governance that is Attributed to inequitably in allocation of land, unclear property rights, irrational economic decisions, and this is a common feature of any land delivery system due to bureaucracy, conflict in tenure system, staffing constraints, lack of support services, low morale and corruption at all levels and agencies. As a result it simply rises tenure insecurity of land, a land bad information, discouragement of land investment, and social instability “

It confirmed that the institutionalization of the principles of good governance becomes a necessity in the land administration system in Yogyakarta particularly.

In general, the land has become a dimension of public affairs and public institutions such as the government's most important for several reasons:

a. piece of land is important elements sovereignty and sustainability;

b. land becomes essential element of people's lives

c. closely concerned with public infrastructure

d. important element in the layout of a region

e. part of the most basic needs (human rights) of each individual

Fundamental position of the land in the public affairs dose requires a high level quality of 
governance because only by this circumstance, the land policy will be later as a determinant for achieving people's better prosperity. Country that is richer in natural resources may not necessarily more prosper than the little country of its natural resources. It is a paradoxical as such condition called as Dutch disease. Dutch Disease illustrates a gap of state capacity and its natural resources. This state is circled by a social instability and lack of human resource and technology.

Legally, the disaster occurs in human dimension called as a force major. For this, human kind can be innocence because of out of human capacity. But, every single legal subject must perform precaution. The question is who must be responsible to tackle and overcome the effects of disaster. State and its authority and capacity as the highest level of organization entities must not deny to achieve efforts, in terms of prevention and tackling disaster. Moreover, land matters is one of the most critical public goods in which government generates land policy to respond $\mathrm{A}$ to $\mathrm{Z}$ of the disaster matters on it.

\section{B. Profile of the Yogyakarta Special Region}

Started at the Giyanti Political Contract in 23 February 1755 among three parties ( Prince MangkuBumi I, Pakubowono II, and the Dutch Colonist Government), the Kingdom of NgayogyakartaHadiningkrat was established and authorized to govern certain territories:

a. KuthoNegari where included all regions of Yogyakarta Special Regions presently ;

b. Negara agung (countryside) consisted of Pajang, Kedu, Magelang and Banyumas;

c. Mancanegari comprised Madiun, danBlora

Unfortunately, after the Prince Diponegoro War (1825-1830), he was defeated by Dutch Army and later regions had been reduced and those regions became less territories, later, those become territories of the Yogyakarta Special Region right now.

That time, the King's authority is absolute and centralized upon him, nobody could appeal him. As a result, the king power is very strong on the land matters until now. Fundamentally, citizen can not possess the parcel unless given by the king. People could only own the right of use ( hakpakai)

But in the advance, land policy was developed better time to time. Interval changes of land policy could be divided from starting of the colonist power to the era of Indonesian government. as follows. Starting in 1918, both Sultan and Pakualaman were issuing Rijksblaad (like the king decision) No. 16 and RijksbladPakualaman No. 18, in which citizens' land right were guaranteed better than previous one. It was also as starting regulation to modernize the Yogyakarta Special Region Land Administration until now. As known, the modern form of land policy recognized a clear separation between the land right of sultanate ground and the citizen land right personally. It used to inspire dualism land law in the Yogyakarta Special Region land administration system later. In 1954, based on Article 18 the Indonesian Constitution, state declares recognizing the local government units based on autonomy and privilege in to respect the historical and aboriginal. rightsfirst step was taken by central government by giving full authority of land matters to The 


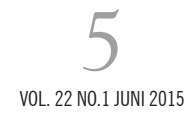

Yogyakarta Special Region. It was supported by The law No 3/1950, than remedied by the Law No. 19/1950. The

The decade later showed the most monumental masterpiece. In 1950, the Yogyakarta Province born with the different attribution as the Special Region or Special Province based on the Yogyakarta Special Province Act No 3 Year 1950 and than remedied by thetheYogyakarta Special Province's Act No 19 Year 1950. The Act stated the existence of a self government on several authorities included land matters.

By 1960, September 24, Indonesia enacted the Basic Regulation of Agrarian Principles, abbreviated as Basic Agrarian Law (BAL) in which Article 4 stated that Customary Land Law ( HukumAdat Tanah) is as the basis of the national agrarian law system because it is the Indonesian aboriginal law. The basic regulation mentioned that held strongly on it comprise: nationalism on the land and natural resources (see Article 33 Constitution); recognition of state authority that may be decentralized to the local government through certain schema of governmental policy

From 1960 to 1984, BAL was not valid in the Yogyakarta Special Region. Then, Started at September 1984 , BAL is having a legal force until now. Its validity is focused on non the shultan ground (land). Therefore, there are two authorities on the matters in the Yogyakarta Special Province, one hand, the state governed lands are managed by central government authority and the sultan ground is managed by the Governor ex officio of the King of Yogyakarta Kingdom that in a practice is administered by PanitiKismo ( the Yogyakarta Kingdom's Land Agency) The existence of the Yogyakarta Kingdom's land administration system is always recognized by all power from earliest colonist to the latest one, Japan.

On 2012, after a long and exhausting struggle, DIY finally confirmed again as a special area with the approval of Law No. 3 Year 2012 on the Special Region of Yogyakarta. There are so many parties who had doubted whether the Yogyakarta is still worthy of the privilege, particularly on land matters. The climax, in the end of 2012 there is a compromise to integrate conservative values and modern principles. The Act No. 3 Year 2012 has been believed to be a compromise in such a way that Yogyakarta Province is being Special Region with clauses as included in the Act. This law confirms the inherent features of 5 specialities are: the appointment of the governor, institutional, and institutions, culture, land, and spatial use.

Article 7 confirmed that the DIY authority as an autonomous region included the authority of DIY Regional Government matters referred to in the legislation on local government affairs and privileges set forth in Law not in the other regulation, while authority in the affairs of others while privileges referred to in subsection (1) include:

a. Procedure for filling the occupation, position, duties, and authority of the Governor and Deputy Governor;

b. Governmental Institution of DIY

c. Culture

d. Land; and 
e. Spatial Use Planning

While the spatial planning is set as follows, Article 34 confirmed that authority in the Sultanate and the Kadipaten in spatial was limited into management and utilization of Sultanate land and Kadipaten land. Is also confirmed the limitation on implementation of the Sultanate or Kadipaten authority in establishing a general framework of the spatial land policy according to the specialty of DIY. The general framework of their spatial use policy must be set accordingly by the national spatial attention and spatial DIY.

\section{Incorporating Principles of Good Governance in Land Policy}

The result of research shows that the implementation of good governance principles on the land administration system in DIY elaborated in an entire land policy.

Decency And Justice Principles In Land Policy of The Yogyakarta Special Region There is evolution from elitism to populis plot.

In its development, to ease burden of the people and avoid any economic disparities, Sultan and

PakuAlam held a reorganization of economic and agrarian. Reorganization undertaken by the release of 16 in 1928 Rijksblad Sultanate and PakuAlamanRijksblad No.18 of 1918. The new rules are:

a. Deleting system lungguh / apenage, palace officials who used to be given in the form of salary appanage / land office abolished and replaced with pay in cash.

b. Forming Kelurahan (sub-urban governments) and given land (tanahkasdesa), the results of the land used for financing urban governance andcommunity development as well as salaries for village officials.

c. Providing a strong land rights for kawulo (palace staffs), the people are given the landright of use that could be inherited, sold or mortgaged.

d. Changing radically the basis of the land lease.

That is the right of a person to manage or cultivate land that does not belong to him. To manage or cultivate land that does not belong should permit the village head first.

\section{Institutionalization of the Responsiveness Principle on The Customary Land Rights}

To respond and strengthen customary land rights are then applied Act No.5 of 1960 On The Basic Agrarian Law (BAL) by the government is to eliminate dualism in legislation in the agrarian sector in the province. That is the agrarian law which is based on customary law, agrarian law and is based on western law. But for the province of Yogyakarta region implementation still remember the validity Law No.3 of 1950 on the formation of Yogyakarta Special Province, in the form of regulations concerning its own domestic affairs, including the area of land affairs.

Autonomy of the land matters encouraged DIY'Government to issue a few DIY regional 
regulationsas follows:

a. Yogyakarta Regulation No.5 of 1954 on the Right to Land in Yogyakarta.

b. Yogyakarta Regulation No.10 Year 1954 on the implementation of the village Government Provision regarding to transfer of HakAndarbeni from Kelurahan and Hak Anganggo Turun Temurun and changing of the soil type in Yogyakarta region wide.

c. Yogyakarta Regulation No.11 of 1954 regarding transfer of the inheritable private land right.

d. Yogyakarta Regulations 12 of 1954 concerning the legal certificate for the inheritable private land right.

e. Regulation of Yogyakarta Special Region 31956 on Amendment of Yogyakarta Special Region No. 10 In 1954.

\section{The Transparency and Efficiency Principles in Land Management Policy in Yogyakarta Special Region}

Legal basis of land management policy in the province for realizing the principle of transparency and efficient could be refered to the legislation as follows:

1. Law No. 26 Year 2007 on Spatial Planning (State Gazette of the Republic of Indonesia Year 2007 Number 68, Supplement to State Gazette of the Republic of Indonesia Number 4725);

2. Government Regulation No. 31 Year 1950 on Applicability of Act No. 2, 3, 10 and 11 of 1950;

3. Government Regulation No. 6 of 1988 on Vertical Coordination Agencies (State Gazette of the Republic of Indonesia Year 1988 Number 10, Supplement to State Gazette of the Republic of Indonesia Number 3373);

4. Indonesian Government Regulation No. 39 Year 2001 on Implementation of Deconcentration (State Gazette of the Republic of Indonesia Year 2001 Number 62, Supplement to State Gazette of the Republic of Indonesia Number 4096);

5. Indonesian Government Regulation No. 52 Year 2001 on Implementation Assistance (State Gazette of the Republic of Indonesia Year 2001 Number 77, Supplement to State Gazette of the Republic of Indonesia Number 4106);

6. Indonesian Government Regulation No. 20 Year 2004 on the Government Work Plan (State Gazette of the Republic of Indonesia Year 2004 Number 74, Supplement to State Gazette of the Republic of Indonesia Number 4405);

7. Indonesian Government Regulation No. 58 Year 2005 on Regional Financial Management (State Gazette of the Republic of Indonesia Year 2005 Number 140, Supplement to State Gazette of the Republic of Indonesia Number 4578);

8. Government Regulation of the Republic of Indonesia Number 39 Year 2006 on Procedures for Control and Evaluation of Development Plan (State Gazette of the Republic of Indonesia Year 2006 Number 96, Supplement to State Gazette of the Republic of Indonesia Number 4663);

9. Government Regulation of the Republic of Indonesia Number 40 Year 2006 on Procedures 
for National Development Planning (State Gazette of the Republic of Indonesia Year 2006 Number 97, Supplement to State Gazette of the Republic of Indonesia Number 4664);

10. Indonesian Government Regulation No. 38 Year 2007 on the Government Affairs Division of the Government, Provincial Government of Regency / City (State Gazette of the Republic of Indonesia Year 2007 Number 82, Supplement to State Gazette of the Republic of Indonesia Number 4737);

11. Regulation of the President of the Republic of Indonesia Number 7 of 2005 on the National Medium Term Development Plan 2005-2009;

12. Regulation of the President of the Republic of Indonesia Number 38 Year 2008 on the Government Work Plan 2009;

13. Regulation of the Minister of the Interior of the Republic of Indonesia Number 13 Year 2006 on Regional Financial Management Guidelines;

14. Provincial Regulation of Yogyakarta Special Region No. 1 of 2004 on the Establishment and Organization of the Regional Secretariat and the Secretariat of the Regional Representatives Council Yogyakarta Special Province (Provincial Gazette of Yogyakarta in 2004, Series D, No. 1);

15. Provincial Regulation of Yogyakarta Special Region No. 2 of 2004 on the Establishment and Organization of the Regional Technical Institute on the Environment Government of Yogyakarta Special Province (Provincial Gazette of Yogyakarta in 2004, Series D, No. 2);

16. Provincial Regulation Yogyakarta Special Region No. 3 of 2004 on the Establishment and Organization Regional Office at Government Environment Yogyakarta Special Province (Provincial Gazette of Yogyakarta in 2004, Series D, No. 3);

17. Provincial Regulation of Yogyakarta Special Region No. 5 Year 2005 on Procedures for Regional Development Planning and Implementation Regional Planning Council (Provincial Gazette of Yogyakarta in 2005, Series E, No. 3);

\section{The Quality Services Principles of the Land Matters in DIY}

The application of this principle is based on 10 indicators as follows: Based on the value perception of the 10 indicators, Bantul get perceived value of 59.9953, Gunungkidul 62.1545, and 60.5558 of Sleman regency. Value perception when viewed from the performance of the service unit is sufficient. When compared between Bantul district has a higher perceived value than Bantul and Sleman. Lowest perceived value is Gunungkidul

Therefore, in addition to access to the land information is subject to the laws and regulations in the field of land services are also subject to the laws and regulations of the public merit system.

Principles of the land information service system in the province include:

a. open

b. current

c. accurate 

d. responsible
e. proportionality

\section{Good Land Governaance in Implementation of the Permanent Residence Establishment Program (Hunian Tetap) After the Merapi Disaster \\ 1. Case Profile}

The disaster of Merapi eruption is the natural phenomenon which is happen regularly, every two years, four years, or five years. But, merapi eruption which is happened in October and November 2010 is the worst eruption that ever happened. The eruption along with volcanic dust rain from Merapi Mountain and lunge of cold lava in two provinces namely Central Java (Boyolali, Klaten, Magelang) and Yogyakarta Special Region (Sleman). Besides that, disaster also causes the economic of society become paralyzed because the facilities of economic such as market, plantation, forest were broken and it caused by the lunge of volcanic cold lava and hot cloud, volcanic dust and cold lava flood.

Sleman Regency is a region where known by sight the most serious damage caused by Merapi disaster, because the detritus of lava and hot could, volcanic dust and lunge cold lava tend to move to the south direction. Automatically, Sleman Regency also got worse damange rather than others regency. Based on the data which is produced by BadanPerencanaan Pembangunan Daerah (Bappeda) Sleman regency, the value total of corruptness and damage result the disaster is about 5.4 billion Rupiah. This corruptness and damage values are accounted with classified the corruptness and damage in five

\section{Analysis}

Based on the exposure of the research on the application of good governance in post-disaster settlement, analyses, view can be delivered as follows:

a. Legal Certainty Principle

This principle can be elaborated through the existences of official documents such as relevant acts, governmental regulation. Such complete legal foundation could guarantee the process to its results. Regarding with this, Government has created Regulation of BupatiSleman No.27a/ 2011 about reconstruction mechanisms for permanent residencies; The SlemanBupati Provision No 266/Kep/KDH/2011 about the location for relocation and reconstruction on Merapi Disaster; the BupatiSleman Provision No 77/Kep.KDH/2012 ; Issuing more than 2000 land certificates.

b. State Officer Order

All associated Officers must stand on the right track of land planning policy, the spatial use policy in which all those regulation direct comprehensively on how to process land administration system 


\section{0}

c. Public Interest

Common interests such as the environment sustainability, safety, common prosperity, common aspirations, basic needs must be on a first priority. Factually, this was incorporated in the land planning project. Land administration system recorded a well implemented plan on land tenure, land use, and a increasing value of land.

d. Transparancy

Transparency in the process of development of the post-disaster occupancy stay trim has a meaning that laws, regulations, institutions involved, processes, plans and decisions are made accessible to the public or at least the public representatives.

Transparency requires governments or voluntarily and actively providing complete information to the public through print and electronic media. Especially regarding the selection requirements, plan, design and procurement programs. Based on these results it can be said that the residential development process remains transparent've done this can be seen in the legislation that the legal basis in residential construction is still in Sleman regency of Sleman Regent Rule 27a No. 2011 concerning Residential Development Mechanism Post-Disaster Fixed Mount Merapi, Sleman Regent Decree No. 266/Kep./.KDH/A/2011 on Construction Site Keep In Order Post-Disaster Rehabilitation and Reconstruction Merapi in 2010, Sleman Regent Decree No. 77/Kep.KDH/A/2012 on the Team Assistant for the Rehabilitation and post-disaster reconstruction areas Merapi eruption which was enacted in the sheet area so that people can know.

Reports of progress in implementing permanent residential development through a variety of local and national print media such as websites and electronic www.sleman.go.id Sleman regency government, or on the website REKOMPAK Java Reconstruction Fund (JRF), www.rekompak.jfr.org.which contains documentation, financial reports, progress reports on the implementation of permanent settlements Post Merapi residents are updated every week in accordance with developments in the field.

e. Balance

Taking balance on right and obligation in each corner of mitigation projects particularly in land administration system has been enforced. Even for people who did not want to be relocated, Government guarantee to give them subsidies in seeking parcel of land and reconstruction. Total 592 people did not want to be moved to other places. Yet, government still give them legal protection.

f. Professionalism

Every single duties has done based on etiquettes, regulations, competence and expertise. The numerous jobs were delegated upon its expertise.

g. Accountability

Accountability means that government agencies or public corporations and public officials on the one hand and the private sector, companies and parties that play a role in the company on 


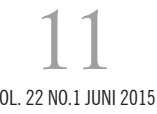

\begin{tabular}{|c|c|c|c|}
\hline NO & $\begin{array}{l}\text { PRINCIPLES OF } \\
\text { GOOD LAND GOVERNANCE }\end{array}$ & INDICATOR & IMPLEMENTATION \\
\hline 1 & Law Certainty & $\begin{array}{l}\text { Theexistence of legal foundation Giving land } \\
\text { certificate }\end{array}$ & implemented \\
\hline 2 & The order civil staff & $\begin{array}{l}\text { Availability of representative Team Controlled } \\
\text { administration }\end{array}$ & implemented \\
\hline 3 & Public participation & Social engagement & Not enough \\
\hline \multirow[t]{4}{*}{4} & Transparence & $\begin{array}{l}\text { Socialization Information assessment } \\
\text { Website availability }\end{array}$ & Implemented \\
\hline & & www.sleman.go.id & \\
\hline & & www.dppd.sleman.go.id & \\
\hline & & www.rekompak.jff.org & \\
\hline 5 & Professionalism & Full facilitation Partnership & Implemented \\
\hline 7 & Balance & $\begin{array}{l}\text { Land availability Verification } \\
\text { information management Weekly And monthly the } \\
\text { program report Availability of performance } \\
\text { report on accountability The control system by BPKP, } \\
\text { BPK and KPK }\end{array}$ & Implemented \\
\hline 9 & Efficiency and effective & $\begin{array}{l}\text { Funding resources from many parties such: } \\
\text { Java Reconstruction Fund (JRF)and Qotar Telcom } \\
\text { Given free land certificates } \\
\text { Finishing program on time Effective process and } \\
\text { the results of permanent residence acquisition. }\end{array}$ & \\
\hline
\end{tabular}

the other hand, should be able to give an gugatkan jobs and tasks, as well as all the decisions and responsibilities. Full accountability procedures should be systematic and can be applied.

Based on these results we can say that accountability in residential construction remained in Sleman district meets the accountability of this is evidenced by the documentation and report progress on implementation and management information systems (MIS) permanent residential development through a variety of government websites Sleman www.sleman.go.id, or on the website REKOMPAK Java Reconstruction Fund (JRF), www.rekompak.jfr.org, as well as the supervision of the implementation of the financial management of the elektrorat Regional Offices, BPKP, BPK and KPK.

i. Effectiveness and Efficiency

The result can be realize on the targeted criteria. Objectives, Cost, and process could be achieved in line the given criteria and indicators (see table)

\section{CONCLUSION}

1. Configuration of the land administration systems in achieving people prosperity has been affected by evolution of political, cultural, and legal awareness of local communities and central government policy.. 


\section{JURNAL MEDIA HUKUM}

2. Incorporating a disaster response based land policy principles requires an integrated law and policy making system among parties through the implementation of good governance principle in the record of public participation voices and sustainable development interests.

3. Notable reports illustrate that the good land governance incorporation encouraged and inspired land planning system to be more efficient and effective

4. Particularly in the natural disaster mitigation and reconstruction, incorporating good land governance principles furthermore encourages land policy makers to achieve the responsive land management in line with social demands and sustainable development programs.

\section{REFERENCES}

Budi Harsono, (2010) HukumAgraria Indonesia, Sejarah, Isi, danPelaksanaan, UniversitasTrisakti, Jakarta

Land Equity International Pty Ltd, (2006), Land Administration:Indicators of Success, FutureChallenges, Suite 12-13 / 74 Kembla St, Wollongong, NSW, Australia 2500

Land Equity International Pty Ltd, (2006),LAND ADMINISTRATION REFORM: Indicators of Success, Future Challenges, Suite 12-13 / 74 Kembla St, Wollongong, NSW, Australia 2500

Maria Soemardjono,(2011), HakSosialdanEkonomidalam Tanah, Kompas,Jakarta

StigEnemark, Denmark, and Paul van der Molen, the Netherlands, (2008) Capacity Assessment inLand Administration, The International Federation of Surveyors (FIG)KalvebodBrygge 31-33 DK-1780 Copenhagen V DENMARK

Abdullah Al hasan, Stephen B. Young , 2008, Guidance for Good Governance, Exploration in Qur'anic, Scientific and Cross-cultural Approaches, IIUM, Coux Round Table

AbdurahmanAbdulkadirKurdi, TatananSosial Islam, StudiBerdasarkan Qur'an danSunnah, translated by IzzamuddinMakmur, Published by PustakaPelajar, Yogyakarta, 2000

AgusDwiyanto (editor), Mewujudkan Good Governance MelaluiPelayananPublik, GadjahMada University Press, CetakanKetiga 2008.

Ahmad Sukardja, PiagamMadinadanUndang-UndangDasar 1945, Disertasi, KajianPerbandingantentangDasarHidupBersamadalamMasyarakat Yang Majemuk, BadanPerbit UI, Jakarta 1995

Alain Marciano , 2009, Law and Economics, A. Reader, . Publisher: Routledge, London and New York.

Alcorn, J. B. 2000. An introduction to the linkages between ecological resilience and governance.InIndigenous social movements and ecological resilience: Lessons from the Dayak of Indonesia, ed. J.B. Alcorn and A.G. Royo.

Alden Wily, L., and S. Mbaya. 2001. Land, people and forests in eastern $\mathcal{E}$ southern Africa at the beginning of the $21^{\text {st }}$ Century: The impact of land relations of the role of communities in forest future. Geneva, Switzerland: IUCN-EARO.2001.

Allan W Shearer and Friends, 2009, Land Use Scenarios, Environmental Consequences of development, 


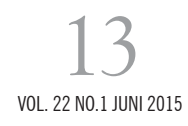

, CRC Taylor \& Francis group,

Abdul Hakim Garuda Nusantara, HakAsasi, LingkunganHidupdan Pembangunan Berkelanjutan, ANDAL, Jakarta, 1990

AbrarSaleng, HukumPertambangan, UII Press, Yogyakarta, 2004

Absori, PenegakanHukumLingkungan, Muhammadiyah University Press, Solo, 2000

AgusDwiyanto, ReformasiBirokrasiPublik di Indonesia, PusatStudiKependudukandanKebijakan, UGM, Yogyakarta, 2002

Anonim, Profil Daerah Kabupatendan Kota, PenerbitBukuKompas, 2001

AsepWarlan Yusuf, Pokok-PokokWewenangPemerintahandalamPengelolaanLingkunganHidup, Jurnal Pro Justitia, tahun XVIII Nomor 2 April 1999, Bandung, 1999

Allan W Shearer and Friends, 2009, Land Use Scenarios, Environmental Consequences of development, , CRC Taylor \& Francis group,

Alpha Amirrachman, ReitalisasiKearifan local, StudiResolusiKonflik di Kalimantan Barat, Maluku danPoso, ICIP, 2006

Bagir Manan, Hubungan antara Pusat dan Daerah Menurut UUD 1945, Pustaka Sinar Harapan, Jakarta, 1994

Bediuzzaman Said Nursi, Nature, Cause or effect?, Sozler Publication, 2010

Blaikie, P., and Brookfield, H. (eds.) (1987).Land Degradation and Society, Methuen, London.

BindeMcMorland\&Sim, 1986, Introducation to Land Law 2nd Edition, Butterworths,

Boomgaard, P. (1989). Between Sovereign Domain and Servile Tenure: The Development of Rights to Land in Java, 1780- 1870, Free University Press, Amsterdam. (Comparative Asian

Studies, 4).

Boomgaard, P. (1997). Hunting and trapping in the Indonesian archipelago, 1500-1950. In Boomgaard, P., Colombijn, F., and Henley, D. (eds.), Paper Landscapes: Explorations in the Environmental History of Indonesia, KITLV, Leiden.

Boomgaard, P. (1999). Oriental Nature, its Friends and its Enemies: Conservation of Nature in LateColonial Indonesia, 1889-1949. Environment and History 5: 257-292.

Boomgaard, P. (2005). The long goodbye?Trends in forest exploitation in the Indonesian Archipelago, 16002000. In Boomgaard, P., Henley, D., and Osseweijer, M. (eds.), Muddied Waters: Historical and Contemporary Perspectives on Management of Forests and Fisheries in Island Southeast Asia, KITLV, Leiden. Blaikie, P., and Brookfield, H. (eds.) (1987). Land Degradation and Society, Methuen, London. Boomgaard, P. (1989). Between Sovereign Domain and Servile Tenure: The Development of Rights to Land in Java, 1780- 1870, Free University Press, Amsterdam. (Comparative Asian Studies, 4).

Boomgaard, P. (1999). Oriental Nature, its Friends and its Enemies: Conservation of Nature in LateColonial Indonesia, 1889-1949. Environment and History 5: 257-292.

Boomgaard, P. (2005). The long goodbye?Trends in forest exploitation in the Indonesian Archipelago, 16002000. In Boomgaard, P., Henley, D., and Osseweijer, M. (eds.), Muddied Waters: Historical and Contemporary Perspectives on Management of Forests and Fisheries in Island Southeast 


\section{4}

Asia, KITLV, Leiden.

Budi Harsono, 2002, Sejarah, Isi dan Pelaksanaan Hukum Agraria di Indonesia, Djambatan

Hukum Agraria Indonesia, Himpunan Peraturan-Peraturan Hukum Tanah, Edisi Revisi, Djambatan, 2009

Budiono. 2001. Ekonomi Internasional. Badan Penerbitan Fakultas Ekonomi. Universitas Gadjah Mada. Yogyakarta.

Cameron Blackhall J., 2005, Planning Law and Practice, Third Edition, , Cavedish publishing,

Clare Cumberlidge and Lucy Musgrave, 2007, Design and Landscap for people, New Approaches to renewal, , Published: Thames and Hudson,

Christopher Pollitt and Geert Bouckaert, 2008, Publick Management Reform, Comparative Analysis, by, Published Oxford, 2nd.

David E. MCNABB, 2009, The New Face of Government, How Public managers are forging a New Approach to Governance, By, CRC Press, Taylor \& Francis Group

Denny Indrayana, Indonesian Cnstitutional Reform 199-2002, An Evaluation of Constitutionmaking in Transition, Kompas, Jakarta, 2012

DIKTI, PanduanPelaksanaanPenelitiandanPengabdianKepadaMasyarakat di PerguruanTinggi, DP2M, Kemen DIKNAS, Jakart, 2013,

Donald iller and Gert de Roo, 2004, Integrating City planning and Environmental Improvement, Practicable Strategies for sustainable Urban development, , Published, ASHGATE,

E. Utrecht, PengantarAdministrasi Negara, PustakaTintaEmas, Surabaya, 1988

East Asian/ASEAN Rice Reserve System. 2002. Summary of Proceeding of The First Technical Meeting on Rice Reserve (TMRR I). dalamSuryana, A. danHermanto. 2004. dalam Kasryno, F. AM. Fagi, dan E. Pasandaran (Ed.). Ekonomi Padi dan Beras Indonesia. Badan Litbang Pertanian, Departemen Pertanian.

UN ECOSOC for Europe, Land Adaministration in The UNICE Region, New York and Genewa, 2005.

EggiSudjana, PenegakanHukumLingkungandalamPerpektifEtikaBisnis di Indonesia, Gramedia, Jakarta, 1999

Erwidodo. 1999. Effects of Trade Liberalization on Agriculture in Indonesia: Institutional and Structural Aspects. The CGPRT Centre.Working Paper No 41.

Erwidodo and P.U. Hadi. 1999. Effects of Trade liberalization on Agriculture in Indonesia: Commodity Aspects. Working Paper Series No 48.CGPRT Center. Bogor.

Fadilah Putra, Senjakala Good Governance, Overrcross Press, Malang, 2009,

Foster, Phillips. 1992. The World Food Problem: Tackling the Causes of Undernutrition in the Third World. Lynne Rienner Publisher, Boulder.

GoktugMorcol, 2007, Handbook of Decision Making, Public Adminitration and Public Policy123, Published CRC Press, Taylor and Francis Group,

Government of Indonesia. 1983. A Study of the Regional Physical Planning Program for Transmi- 


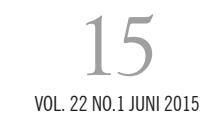

gration. Dept of Transmigration Rep.4

Government of Indonesia. 1985-1990; 1993-1998. Land Resource Evaluation and Planning Project.5

Government of Indonesia. 1997. Agenda 21 Indonesia: A National Strategy for Sustainable Development. Office of Minister of State for Environment, March 1997, Jakarta.

H.G. Wells (editor), Short History of The World, SejarahDuniaSingkat, Cetakan 3, IndoLiterasi, 2013

Haddad, L. 1997. Achieving Food Security in Southern Africa: New Challenges, New Opportunities.International Food Policy Research Institue, Washington, D.C.

Hafsah, J. 2004. Strategy and Policy on Rice Production in Sub Optimal Agroecosystem. Paper presented on Seminar on Rice and Rural Prosperity. IAARD.December 7-8. Jakarta.

Hamdy, H. 2000. Ekonomi Internasional: Teori dan Kebijakan Perdagangan Internasional. Buku Kesatu. Ghalia Indonesia. Jakarta.

Ibnu Katsir, Shahih Tafsir Ibnu Katsir, Jilid 1-9, Pustaka Ibnu Katsir, Bogor, Cet I, 2007

Imam Al Mawardi, , Al AhkamAshulthoniyah,Prinsip-PrinsipPenyelenggaraan Negara Islam, Published by DarulFalah Publishing, Jakarta 2001

Indrawati, S.M. 1995. Liberalisasi dan Pemerataan. dalam Liberalisasi Ekonomi,Pemerataan dan Kemiskinan. Soetrisno, L. dan F. Umaya (Editor). PT.Tiara Wacana Yogya. Yogyakarta.

Jacqueline martin \& Chris Turner, 2004, Unlocking Law, Judith Bray, Series editors

J.C.T. Simorangkir, PenetapanUndang-UndangDasarDilihatdariSegiIlmuHukum Tata Usaha

Negara, Disertasi, GunungAgung Publisher, 1984

HadiPodo, KamusUngkapan, GramediaPustakaHarapan, Cetekan IX, 2003

Jeffrey M Paige, RevolusiAgraria, GerakanSosialdanPertanianEkspor di Negara-Negara DuniaKetiga,

Emperium Publisher, 2011

JimlyAsshidiqie, PengantarIlmuHukum Tata Negara, Rajawali Press, Jakarta, 2009 , Green Constitution, NuansaHijau UUDRI 1945, Published by RajagrafindoPersada, Jakarta, 2009,

--_-_-_-_, PerkembangandanKonsolidasiLembaga Negara PascaReformasi, MahkamahKonstitusi, 2006

Mark. P. Thompson, (2012) modern land law, Oxford University Press

John Steven, , Land Law, Sweet \&Maxwell, UK(2013

Judith Bray, Unlocking Land Law, Hodder Education, London2013,

Judith Bray, Unlocking Land Law, 3th edition, Published by HODDER EDUCATION, London, 2014

K.C. Wherare, Konstituti-Konstitusi Modern, Pustaka Eureka, Surabaya, 2003

Koutsoyiannis, A. 1977.Theory of Econometrics.Second Edition. Harper \& Row Publisher, Inc.

The Macmillan Press Ltd. London.

Koesnadi Hardjasoemantri, Hukum Tata Lingkungan, Edisi Ketujuh, Cetakan kelimabelas, Gadjah 
Mada University Press, 2000

Taqwaddin, Sulaiman Tripa, Insa Ansari, Teuku Muttaqin Mansur, Penyelesaian Tanah Korban Tsunami Yang Tidak Ada Dan/atau TidakDiketahui Ahli Warisnya, Jurnal Media Hukum, Vol. 19, No. 2, 2012 